\title{
WHY BLEND CONVERSATION ANALYSIS WITH COGNITIVE GRAMMAR?
}

\author{
Marja Etelämäki and Laura Visapää
}

\begin{abstract}
This article proposes that combining Conversation Analysis (CA) with Cognitive Grammar (CG) provides a fruitful framework for studying language as a socio-cognitive phenomenon. The authors first discuss two indexical phenomena, the Finnish demonstratives and the Finnish free-standing infinitives; these are first analyzed using the methods of CA, then rediscussed in the framework of CG. The description of both phenomena relies on the CG notion of grounding elements, i.e., the elements that conceptualize some facet of the ground (speech situation) as part of their meaning. The authors argue that such meaning associated with grammar includes knowledge about the schematic organization of the ground, and that the grammatical means for conceptualizing the ground make dynamic co-construction of the speech situation possible. Whereas the authors rely on the terminology of CG when describing the construal of the ground, they strongly underline the fact that the ways in which the ground is construed can only be found out using the methods of CA. In this way, combining CA with CG can offer us an approach where language is analyzed as the interface of the human mind and the social world.
\end{abstract}

Keywords: Interaction; Construal; Ground; Demonstratives; Infinitives; Cognitive grammar; Conversation analysis.

"Fair minds will recognize that, in having an account in semantics which is neither exhaustive nor definitive, CG hardly stands alone. Yet, because it accepts the centrality of meaning and tries to say something both substantive and psychologically plausible about it, the deficiencies are especially apparent. -- complete semantic descriptions cannot realistically be envisaged. Any actual description must limit itself to facets of the total meaning that are either central or relevant for a specific immediate purpose. If they are principled, linguistically revealing, and empirically supported, even partial characterizations are valid and useful.” (Langacker 2008: 11.) 


\section{Introduction}

In this article, we will suggest that combining the method of conversation analysis (CA) with the theory of cognitive grammar (CG) would benefit the theoretical and descriptive aims of interactional linguistics. ${ }^{1}$ Langacker's cognitive grammar (see esp. 1987, 1991, 1999, 2008) has not been the most cited one in interactional studies on language: It has been described as armchair driven (see Etelämäki, Herlin, Jaakola, and Visapää 2009), and a theory that promotes a static and egocentric view of the speech situation (e.g. Laury 2002). We will propose, however, that the combination of CA and CG would result in a more satisfactory understanding of language-in-interaction: It would provide us with a more detailed description of the subtle ways in which grammar contributes to the interactional organization of social situations.

Blending conversation analysis with cognitive grammar might seem surprising, as the interactional and cognitive approaches to grammar are easily seen as mutually exclusive alternatives to each other. One of the central issues contributing to this division - whether explicitly formulated or left undefined - is the question of where grammar is located. From the point of view of cognitive grammar, grammar resides in the minds of the interactants. In interactional approaches, on the other hand, the individual mind is not seen as the right place to look for grammar: Grammar and meanings are seen as emerging dynamically in discourse and social interaction (see e.g. Goodwin 1979; Schegloff 1996; Ford \& Thompson 2003; Auer 2005). Cognitive dimensions of language are understood as referring to the internal processes located in the mind of an isolated individual, cognitive linguistics being interested in the ways in which linguistic forms are used for the formulation of articulated thought - a view advocated by many cognitive linguists, too (see e.g. Kemmer 2011). In this line of thinking, the static view ascribed to cognitive semantics is quite understandably seen as incapable of handling the intersubjective and context-dependent nature of meaning construction in actual discourse (see also Langacker 2008: 28).

It is here, however, where we think cognitive linguistics, or at least cognitive grammar, has been harshly misinterpreted (see also Etelämäki et al. 2009). The theory explicitly states that cognition is not something located inside an asocial, acontextual skull. Although grammar is seen to reside in the minds of interactants, cognition is understood as inherently social; consequently, grammar is seen as a thoroughly social phenomenon, which is learned in and abstracted from social situations (Langacker 2008: 28; Croft 2009; Zlatev 2010). Cognitive grammar is thus fundamentally a usagebased model of language structure, taking as its starting point the idea that usage events are the source of all linguistic units (Langacker 2008: 220-221, 457-459; Barlow \& Kemmer 2000; cf. also Bybee \& Hopper 2001). Although research carried out within cognitive grammar indeed often concentrates on the speaker, and the choice of research interests and the handling of data - if used at all - give the impression that its central theoretical aims lie in the analysis of an isolated individual's grammar, we believe that

\footnotetext{
${ }^{1}$ Many of the ideas presented in this paper have been developed together with Ilona Herlin and Minna Jaakola, to whom we are grateful for discussions and long-time cooperation. The ideas presented in this paper have their roots in the 2009 paper by Etelämäki, Herlin, Jaakola and Visapää. Etelämäki would also like to acknowledge support from the Freiburg Institute for Advanced Studies (FRIAS), which provided her an opportunity to work on ideas presented now as parts of this paper (especially the description of demonstratives in the framework of cognitive grammar (3.2)) as a junior fellow during fall 2009.
} 
one should not throw the baby out with the bathwater. Inaccurately described details concerning the speech situation do not make a whole theory useless but instead call for a revision, in the light of empirical data and a proper method for analyzing them.

The basic assumptions of cognitive grammar were included in some of the first papers that represent the field of research now being referred to as interactional linguistics. E.g. Ono \& Thompson (1995: 216) describe conversational syntax as follows:

\footnotetext{
”We concur with Jespersen (1924) and Langacker (1987: 57) in conceiving of 'grammar' - 'dynamically, as a constantly evolving set of cognitive routines that are shaped, maintained, and modified by language use'.”
}

According to Ono and Thompson, "the grammar of a language can be understood as a structured inventory of such patterns (Langacker 1987: 63, Fillmore 1988: 37)”. In addition to stressing the importance of taking into account such abstract schematic patterns, they point out that the ways in which these patterns are realized can only be understood with respect to the physical and social factors related to face-to-face interaction and should therefore be studied in interactional, empirical data.

In our article, we, too, approach grammar from both perspectives, as a dynamically emerging social product as well as a cognitive repository of conventionalized interactional meanings and practices. In many respects, our view is thus similar to Ono and Thompson (1995). What we find problematic, though, is that since Ono and Thompson (1995), the description of semantic phenomena has largely been neglected in interactional linguistics. There is a large body of research that describes how language is used in interaction and analyzes the interactional functions of specific linguistic elements. However, no attempts have been made to present semantic generalizations about them. This is a controversial issue, which is connected to the assumptions one makes about the linguistic knowledge that participants bring to the interactional situations with them. Our aim is to arrive at some sort of generalization, however partial and tentative it might be. We analyze grammar as emerging and emergent in interaction, i.e., a dynamic product of interaction, and at the same time as a sedimented product of interaction that manifests the sociality and intersubjectivity of the human mind (Etelämäki et al. 2009).

It is for this reason that we think that cognitive grammar would benefit the description of language-in-interaction if combined with CA. In CG, all form is seen to be endowed with meaning: The linguistic structures that people use carry meaningful organizations with them, and the conventional aspect of meaning-making cannot be left aside, even if language is seen as emerging in interaction. By combining CA and CG, language can be analyzed in a framework that allows enough flexibility for true emergence of actions and linguistic structures in interaction while, at the same time, maintaining a certain amount of stability in grammar, which makes phenomena such as projection possible.

The aim of this paper is theoretical, but everything suggested is rooted in the analysis of naturally occurring interaction. Our approach is thus empirical and usagebased: While we want to underline the usefulness of cognitive grammar as a tool for approaching linguistic meaning, we believe that the use of naturally occurring linguistic data leads us to more accurate descriptive generalizations. The paper focuses on indexical elements of language, which are used for organizing the ongoing interaction; the data consist of audio and video recordings of naturally occurring telephone and face-toface interactions. We will start by examining two linguistic phenomena, Finnish demonstratives and free-standing infinitives, through the lens of CA. Following this, we re- 
discuss the examples analyzed in the first part of the paper, and present three theses that guide our socio-cognitive analysis of interactional phenomena. In the last part of the paper, we discuss the question of interaction and grammar more broadly, as well as the implications that our findings could have for future research.

\section{Finnish demonstratives and infinitives in interaction}

In this section, we will show with conversational data extracts how Finnish demonstratives and free-standing infinitive constructions are used in interaction. The analyses we will present are based on our previous studies (Etelämäki 2006, 2009; Visapää 2008, to appear). We join interactional approaches to language in the claim that conversation analysis is needed for analyzing and understanding the dynamicity and action-oriented nature of talk-in-interaction, and the thoroughly interactional nature of grammar.

Demonstratives are traditionally classified as indexicals; free-standing Ainfinitives, on the other hand, are constructions that lack deictic morphology. In the following, we will first analyze the use of Finnish demonstratives (2.1) and then the use of free-standing infinitives (2.2) in interaction; we will suggest that it is precisely because of the lack of deictic morphology that the free-standing infinitives are used as profoundly indexical constructions.

Semantic description of indexicals has been problematic, even to the extent that they have been claimed to convey no semantic meaning, only pragmatic functions (e.g. Diessel 2006). Non-referential indexical elements such as particles have been ignored in a large body of linguistic research. Yet since the entry of conversation analysis in linguistics, the study of indexicals has seen a boom: There is a growing amount of research on demonstratives and particles that describes their use in interaction (e.g. Hakulinen (ed.) 1989; Hakulinen \& Seppänen 1992; Ford \& Fox 1996; Laury 1997; Sorjonen 2001; Mazeland \& Huiskes 2001; Hakulinen 2001; Keevallik 2003; Etelämäki \& Jaakola 2009; Schegloff 2010; Koivisto 2012). ${ }^{2}$ Our own attempt at combining CA with CG has its origins in our studies on indexicals: It has been clear from the beginning that CA is the method for analyzing their use and meaning in interaction, but finding a semantic theory that would be appropriate for describing this meaning and that would be compatible with conversation analysis has not been self-evident. In section 3, we will propose how to combine the analyses of the use of the demonstratives and infinitives in interaction with the theory of cognitive grammar, and discuss the compatibility of these two approaches.

\subsection{Finnish demonstratives}

Etelämäki (2006, 2009) studied the use of Finnish demonstratives in a corpus of 12 hours of naturally occurring face-to-face and telephone conversations. There are three demonstratives in Finnish: Tämä, tuo and se, their plural forms being nämä, nuo and ne. In present-day colloquial language the demonstrative tämä/nämä takes often the form tää/nää in most Finnish dialects, exception being some dialects spoken in Northern Fin-

\footnotetext{
${ }^{2}$ These studies have been influenced by especially Silverstein 1976 and Hanks 1990, 1992, 2005.
} 
land; the demonstrative tuo/nuo can take the form toi/noi, particularly in Southern and South-Western Finnish dialects (Mielikäinen 1991). While the traditional view on demonstratives has long been that they convey spatial oppositions (proximal and distal) (e.g. Setälä 1880; Penttilä 1963 [1957]; Larjavaara 2007), it was clear from the data that the spatial description does not apply to Finnish demonstratives (see also Laury 1997; on Lao demonstratives see Enfield 2003).

In conversation analysis (see e.g. Schegloff 2007), talk-in-interaction is understood and analyzed as a form of joint action: Language is a vehicle for accomplishing actions in interaction. Using conversation analysis for studying Finnish demonstratives, Etelämäki (2009) proposes that demonstratives are used to coordinate joint perception in interaction (see also Diessel 2006), and that coordinating joint perception is inextricably linked to coordinating joint action (see also Goodwin 2003).

The starting point in Etelämäki's study is that on-going interaction directs the formation of the context: Only those features of the context are relevant that are made relevant in the interaction. This means that context - even the physical environment in the sense of being present for the parties of an interaction - is dynamic: It is in constant change (see Hanks 1990, 2005). Furthermore, the interpretations of the environment and the world as well as the importance of identifying and interpreting the environment change as the conversation goes on. Talk-in-interaction is composed of actions and activities such as inviting, giving advice, complaining, joking, sharing affect and so on. Referent identification and interpretation is not equally prominent in the different things that people do when talking. Furthermore, referent identification and interpretation is not equally prominent in all the phases of a sequentially progressing activity. Demonstratives are used for regulating referent interpretation in interaction, and that way they also take part in organizing the activity (Etelämäki 2009).

The following extract (1) exemplifies the use of the Finnish demonstratives in interaction. ${ }^{3}$ It comes from a conversation between two middle-aged women, Taru and Kati, who are spending New Year's Eve together. In the middle of the conversation, there is a troubles-telling sequence where Taru is complaining about a strange rash in her hand and about the doctor who apparently did not take her worries seriously enough. Jefferson (1988) suggests that troubles-telling sequences have a characteristic trajectory: They are composed of a series of recurrent and positioned elements that can be grouped into a rough segmental order. The trajectory is due to the specificity of troubles-telling as an activity: During troubles-telling the participants align to the trouble simultaneously as they orient to routine conversational requirements, and to each other. During the course of a troubles-telling sequence, the participants constantly negotiate of the course of the talk: Whether it is troubles talk or business as usual, and if it is troubles talk, when and how to proceed to the next phase of the troubles-telling sequence. According to Jefferson (1988: 420), the elements of a troubles-telling sequence and their order in the sequence is:

\section{A Approach \\ B Arrival: Announcement + Announcement response (displays empathy)}

\footnotetext{
${ }^{3}$ The data for examples 1 and 2 come from the Conversation Data Archive, Department of Finnish, Finno-Ugrian and Scandinavian Studies, University of Helsinki. In the transcription of data, references to issues that might lead to recognition of the participants have been changed.
} 
C Delivery: Exposition + Affiliation + Affiliation Response (display of empathy that elicits more talk with a heightened affective stance)

D Work up (incl. diagnoses, prognoses, reports of relevant other experiences, etc.)

E Close Implicature: Optimistic Projection, Invoking the Status Quo

F Exit

In extract 1, lines 1-10 can be analyzed as being part of the troubles-arrival and delivery phase (B and C) and lines 11-18 of the work-up phase (D). Lines 19-28 are closeimplicative (E), but on lines 30-42, the work-up phase is opened up again:

(1)Sparkling wine: Hands (Sg 398)

01 Taru: [siis mul on (.)

PRT 1SG-ADE be.3SG

I mean I've got

02

mä \#\#or rannekellon heittäny po: is =

I be-1sg wristwatch-GEN throw-PPC away

I have thrown [my] wristwatch away

$\odot 3$

$=$ kun $(0.2)>\operatorname{mmul}<$ (.) $\mathrm{m}$ tiedä mistä,

PRT 1SG-ADE know what-ELA

because I have (.) I don't know from where

04

个mä en tiedä mistä tää taas on tullu

1SG NEG-1SG know what-ELA DEM1 again be.3sG come-PPC

I don't know from where this has come again

( ( $\uparrow$ Kati leans

forward to look at Taru's hand.))

05

tämmös [t ihme ${ }^{\circ}$ pahaa $^{\circ}$. ]

DEM1.ADJ-PAR strange bad-PAR

this kind of strange bad

06 Kati:

$\left[{ }^{\circ}\right.$ se on ihan paha]na ${ }^{\circ}$, DEM3 be.3sg all bad-ESS

it is rather bad

07

herrajjumala $\mathrm{ku}{ }^{\circ}$ se on paha ${ }^{\circ}$.

lordgod PRT DEM3 be.3sg bad

good god it is bad

08

(๑.7) ((Kati returns back to normal sitting position))

09 Taru: >n< 个vähän aikaa. Thetken oli poissa ja

little time-PAR moment-GEN be-PST gone PRT

for a little time. for a moment (it) was gone and

10

ny $[\mathrm{t}$ taas

now again

((40 seconds omitted)) 
11 Kati: =túo pitäs: : minum mielest nyt tuto ${ }^{\circ} i^{\circ}$

DEM2 must-CON.3SG 1SG-GEN mind-ELA now examine-A-INF

that should be examined now I think

12

${ }^{\circ}$ ettei siin oo mitään melanoomaah'.

PRT-NEG.3SG DEM3-ESS be any mélanoma-PAR

(to make sure) that it isn't any melanoma

((1 minute 20 seconds omitted))

13 Kati: hei sun on ihan oikeesti näytettävä toi

PRT 2SG-GEN be.3Sg PRT really show-PAS-PC DEM2 hey you really must show that

14

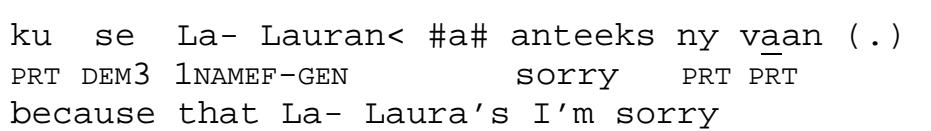

15

[kum mä oon tämmönen \#ö\# kakkiainen PRT 1SG be-1SG DEM1.ADJ poopster/rogue

for being this kind of a poopster/rogue

16 Taru: [joo. joo. eikum siis mun ei

PRT PRT PRT PRT 1SG-GEN NEG.3SG

yes yes not but I mean I'm not

17 Kati: mutta kun [mä olen huo[lissani sinusta .

PRT PRT 1SG be-1SG worried-POSS 2SG-ELA

but I'm worried about you.

18 Taru: [joo. [joo.

PRT PRT

yes yes

((2 minutes 14 seconds omitted))

19 Kati: .hhh että niitä voi:,

PRT DEM3.PL-PAR can.3SG

that they can

20 se voi olla mitä vaa

DEM3 can.3SG be-A-INF anything

it can be anything

21 [että ei sen tarvi olla ]

PRT NEG.3SG DEM3-GEN need be-A-INF

so it doesn't need to be

22 Taru: [niiv voi joo ]

PRT can.3SG PRT

it can yes

23 Kati: [sitä melanoomaa, mutta tuota< se pitää]

DEM3-PAR melanoma-PAR PRT PRT DEM3 must-3SG

melanoma but it must be

[ 


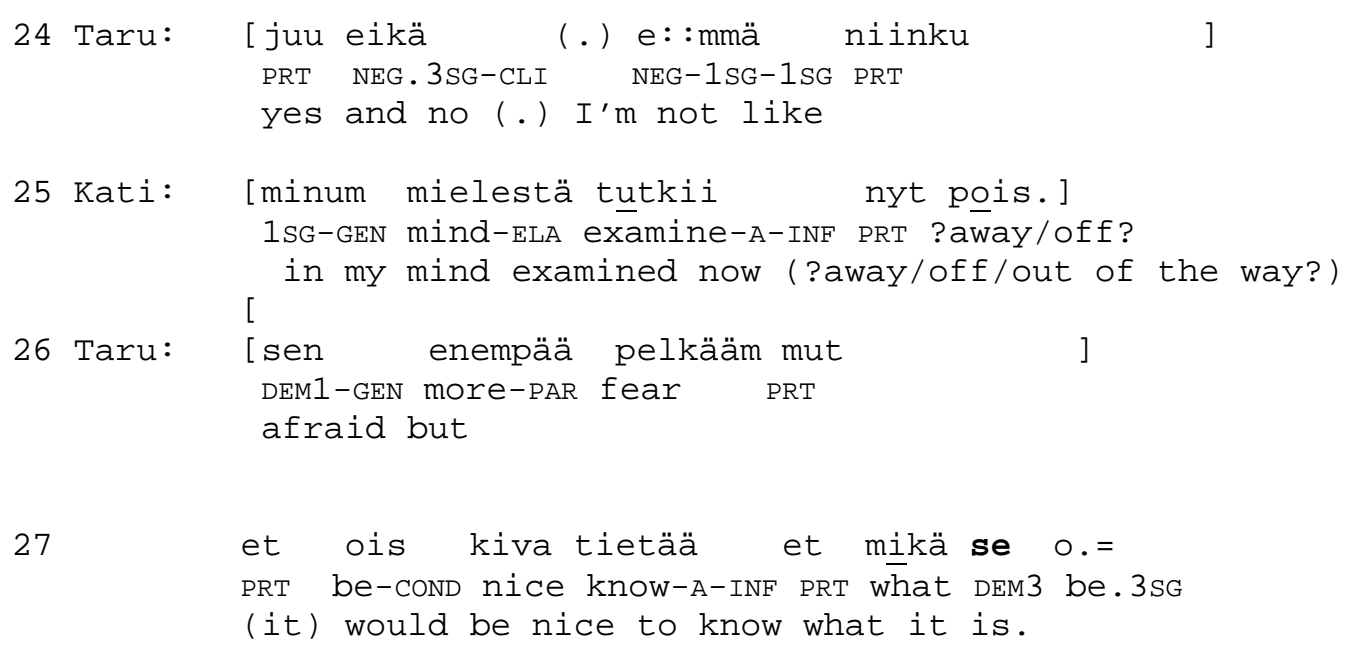

28 Kati: =mm,

PRT

$\mathrm{mm}$,

29

$(0.6)$

30 Taru: \#o\# ja varsinkii siis kum mä niinko mietin sitä PRT especially PRT PRT 1SG PRT think-PST-1SG DEM3-PAR and particularly when I like think about that

31

32

et \#m:illon se oli eka kertaa sillon

PRT when DEM3 be-PST first time-PAR then when was it the first time when I

ku mä >s- lö-si-< satutin PRT 1SG hürt-PST-1SG DEM3-GEN PRT when I hurt it that PRT 1SG think-PST-1SG PRT DEM3.LOC be.3Sg get-PPC some I thought that there has gotten some

yes

( . )

37 Taru: HHh jotenki muhii tos vaanh. somehow brew-up.3SG DEM2-INE just somehow just brews up in there 
39

$4 \odot$

41 Kati:
joO:

yes

$(1.2)$

mmut sit ku se välillä paranee

PRT PRT PRT DEM3 sometimes heal-3SG

but then because it gets well at times

niin se: ei niinku kuulosta bakterilta.

PRT DEM3 NEG.3SG PRT sound. NEG bacterium-ABL

so it doesn't sound like a bacterium

In the extract, Taru uses all three of the demonstratives when referring to her hand and the rash: Tää in line 4, se in line 27, 32 and 33, and the inessive form of toi (tos) on line 37. Kati uses the demonstrative se on lines 6, 7, 12, 21, 23, 41 and 42 and the demonstrative toi on lines 11 and 13 for referring to Taru's hand and the rash. Etelämäki (2009) has proposed that the demonstrative tämä offers the referent as an observable and interpretable object, and also expresses that the primary access to the referent is via the utterance in which the demonstrative tämä occurs, which usually means that the speaker of tämä has primary access to the referent. ${ }^{4,5}$ The demonstrative tuo offers the referent as an observable and interpretable object as well, but it implies that the recipient(s) has/have independent access to the referent. The demonstrative se is used for merely referring to the referent as known enough for the purposes at hand: It does not offer the referent as an observable object. In addition, it implies that the participants of a conversation have equal and sufficient access to the referent. (Etelämäki 2009.)

Lines 1-10 are part of the troubles-arrival and delivery section. By using the demonstrative tää, Taru offers the rash as an observable and indicates that she has primary access to the symptoms in her hand. The symptoms, which she describes during the 40 seconds omitted from the transcript, include pain. When describing the pain, she repeatedly refers to her hand with the pronoun tää: Particularly pain is a highly subjective sensation that only the experiencer has primary access to. In lines 6 and 7, Kati uses the pronoun se in a turn that is a troubles announcement response. The prosodic production of the turn as well as Kati's bodily movements can be seen to display empathy: The turn is produced almost as a whisper, and during the turn Kati leans forward to look closely at Taru's hand. ${ }^{6}$ The pronoun se refers to the hand as known enough for present purposes: It is affective affiliation, a display of empathy and concern that are foregrounded in the turn.

As opposed to lines 6 and 7, in lines 11 and 13 Kati uses the demonstrative toi for pointing at Taru's hand. These lines are from the troubles work-up phase, during which Taru and Kati are negotiating possible diagnoses (melanoma, celiac disease rash, stress), reporting relevant other experiences and remedies. In this phase, observing the hand is foregrounded. Furthermore, after Taru has described all her symptoms and Kati

\footnotetext{
${ }^{4}$ In the case of direct reported speech the speaker of the reported utterance is construed as the one having primary access to the referent.

${ }^{5}$ On descriptions of the demonstrative tämä expressing the speaker's sphere, see Itkonen 1966, 1979 and Laury 1997; see also the discussion in Etelämäki 2009.

${ }^{6}$ Maxi Kupetz, e-mail communication July 25, 2012. In preparation: Empathie-Darstellungen in der sozialen Interaktion. Ph.D. Thesis. German Department, Potsdam University.
} 
has told a relevant other experience (not shown in the transcript), the participants have equal enough access to the rash for the purposes of working up the trouble.

Lines 19-28 are closure-implicative. There are optimistic projections (it doesn't need to be melanoma, I'm not so afraid of it). In addition, both participants use the pronoun se when referring to the hand, offering the referent as known enough, and not any more under observation. That way also the use of the pronoun is part of the closure of the troubles-telling sequence. However, in lines 20-34, Taru initiates a new telling about an earlier potential diagnosis of her hand. In line 37 she again uses the demonstrative toi in its elative case form tos. This re-opens the work-up phase, which can be seen in Kati's response in lines 41-42. However, Kati's use of the demonstrative se is closure implicative, and shortly after this the conversation gradually turns to other matters.

With this extract, we have illustrated the ways in which the Finnish demonstratives are used in interaction. They are used for directing and regulating access and attention to the referent with respect to the activity. In this sense they are used for indexing the activities in interaction as well. However, the link between demonstratives and actions is not direct: There is no one-to-one match between any particular action and a particular demonstrative. The interactants need different kinds of access and different types of focus on the referent in different types of activities and different phases of the activity sequence. We suggest that the demonstratives themselves are minimal in their meanings: They only position the participants and the referent in relation to each other. That way they create different sorts of access, attentional foci and participation roles. When creating access, participation roles and attentional foci they take part in creating and constructing the activities as well.

We cautiously suggest that the semantics of demonstratives might be characteristic of human perception and interaction more generally. In section 3, we will propose a way in which the meaning of the demonstratives can be described schematically within the framework of cognitive grammar.

\subsection{Finnish infinitives}

Our second example comes from the Finnish infinitive system, illustrating the interactional functions of free-standing A-infinitival clauses. An A-infinitive is the basic form of the infinitive in Finnish (cf. Eng. [to] do, Ger. [zu] machen, Swe. [att] göra etc.); it is prototypically used as a subject or object complement of a finite verb or as a modifier to a noun phrase: Voin tulla huomenna 'I can come tomorrow', Onko meillä aikaa puhua tästä myöhemmin 'Do we have time to discuss this later on'. Visapää (2008, forthc.) has suggested that speakers can use A-infinitives not simply as complements or modifiers to finite structures but also as grammatically independent constructions for carrying out affective functions. She suggests that their independent use is appropriate for and motivated by their contexts of use, and need not be explained with reference to "lacking" a finite verb.

Visapää's analyses of free-standing A-infinitives are based on a corpus consisting of 970 instances from modern written Finnish, as well as 20 instances from naturally occurring conversational data. She shows how infinitive clauses are used in responsive, affective functions - in conversational data invariably in sequences in which the participants are assessing something together. A typical case is given in example 2. It comes 
from a sequence in which Pirjo has told a story about a group of Finns she witnessed buying huge amounts of cheap food in Sweden (worth the amount of appr. 700 Swedish crowns, see line 07). She reports this as having been 'fun' (l. 02) in the sense that the actions of the others were so weird that they became amusing: She reports her mother as wanting to leave (01), and then reports herself as objecting to this (lines 1-2, I was like no let's stay), wanting to stay close to the cash register to see how much people were actually buying (l. 04). She is reconstructing an affective situation for the story recipients (see also Günthner 2000; Selting 2010: 231), referring to the affective reactions that she and her mother had observing the people in these circumstances. The unfolding of the events is presented from the perspective of the person observing "the others" at the cash-register, opening up a place for the story recipients to become affectively involved:

(2) Pinging cash register ( $\mathrm{Sg} 91)^{7}$

01 Pirjo: >mutsi oli et lähetää< mä oli et eiku müm be-PST PRT leave-PAS 1SG be-PST PRT PRT $>$ mum was like let's go< I was like no let's

jäädää tsiigaa tää o $t(h) o s i$ hauskaa $k(h) a t t o o$ stay-PAS see.MA.INF-ILL DEM1 be.3sg really fun-PAR watch-A-INF stay and watch this is so much fun to watch

\$ku noi jengi tos menee\$.hh >sit mä jäin oikee< PRT DEM2.PL people DEM2-INE go-3SG then 1SG stay-PST-2SG really when the people go .hh >then I stayed really

O6 Anu: $\quad m[m m$. PRT $\mathrm{mmm}$

07 Pirjo: [kyl se semmost se[ittemääsataa oli melkei jokaisel PRT DEM3 DEM3.ADJ-PAR seven-PAR. hundred-PAR be-PST almost each-ADE it sure was something like seven hundred for each of them

$\odot 8$ Jonna:

$\odot 9$

10 Anu:

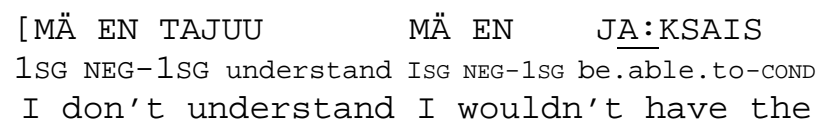

[MÄ EN TAJUU

MÄ EN JA:KSAIS

1SG NEG-1SG understand ISG NEG-1sG be.able.to-CoND I don't understand I wouldn't have the

HEI IKI:NÄ? [ :

PRT ever

energy like ever [ja raahata jostai, $=$

PRT drag-A-INF some-ELA

and to drag from somewhere (like)

\footnotetext{
${ }^{7}$ See footnote 3 .
} 


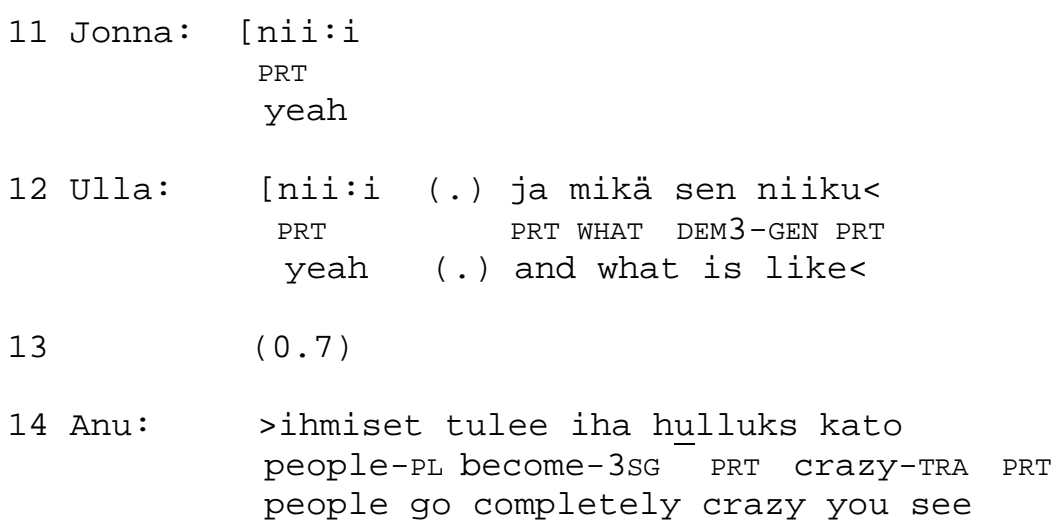

On line 7, Pirjo starts to describe the extreme amount of money that the buyers were using (line 7, it sure was something like seven hundred for each of them). Jonna starts her turn when Pirjo is still speaking, presenting a negative assessment mä en tajuu mä en jaksais hei ikinä 'I don't understand, I wouldn't have the energy like ever' with a loud voice, picking up on the absurdity of the people willing to 'save' money in this way. After Jonna's pronounced IKINÄ 'ever', Anu uses a free-standing infinitive construction ja raahata jostai ('and to drag from somewhere'), aligning with Jonna's turn by assessing the actions of the people described in a negative way, now focusing on the act of dragging. The recipients of the story are displaying a strong affective stance towards the described actions in the here-and-now of the story-telling situation, discussing the point of such action on a more general level (cf. Selting 2010: 240).

The structure that Anu uses in line 10 is grammatically "independent" in the sense that there is no syntactic structure in the nearby context that it would elaborate; this is ensured by the particle ja ('and') in the beginning of the turn: Without the $j a$, the turn could be seen to elaborate the syntactic structure of the previous speaker's turn ('I wouldn't have the energy like ever'). It is left incomplete, however, in the sense that Anu never specifies the location she is referring to with the pronoun jostain ('from somewhere'). For the recipients, the turn is sufficient as such, however, as the to drag from somewhere is followed by Jonna's and Ulla's simultaneously produced responses, two two-peaked nii:is, nii being a response particle that Sorjonen (2001: 133-140) has shown to display the recipient's strong affiliation with the prior speaker's point of view. The infinitival assessment thus elicits a display of affiliation from the other participants, even if it never gets finished.

Visapää (2008) has shown that free-standing A-infinitives are used almost invariably in such affective contexts: They are used for evaluating the prior turn material either positively or negatively (in this respect they resemble the functions of unattached NPs in English, see Ford, Fox \& Thompson 2002: 18, 26) and at the same time, they invite the co-participants to identify with the assessment presented. In written Finnish, one can distinguish nine independent A-infinitive construction types (see Visapää 2008: 35-48). They all share the same basic form in that they are centered around the Ainfinitive, but they can be distinguished on the basis of lexically specified elements and the pragmatic functions they are used for. The functions that are expressed by fixed constructions in writing seem to be produced more locally and flexibly in speech, however, and it does not seem reasonable to talk about fixed A-infinitive construction types in spoken language (Visapää forthc.). The actions carried out with them share something in common, though: They are used in affective contexts, usually in presenting 
assessments. Whether they are used for expressing negative or positive affect always relies heavily on the sequential context.

What unites the uses of such A-infinitive constructions in their various contexts is that they always invite recognition and affiliation from the co-participants, thus resembling the use of Finnish generic personal constructions in many respects - they present generalizations about human experience (on the Finnish zero person construction in affiliation-relevant sequences, see esp. Laitinen 1995, 2006; Sorjonen 2001). Visapää (2008) has suggested that the motivation for their generalizing, affiliation-seeking function lies in their morphosyntactic form: In the fact that in describing processes, Ainfinitives lack personal, temporal and modal marking, whereas Finnish finite verbs are typically marked for these categories. Their morphosyntactic nature thus allows them to be used to present generalizations, making them a useful resource in situations in which co-participants are invited to recognize and align with the affective assessment presented.

In addition to inviting recognition, there is a further interactional motivation for the use of infinitives in assessment sequences. The fact that infinitives remain underspecified with respect to such categories as participants, time and modality can serve as a valuable asset when presenting empathetic responses to affective stories (on the restrictions of such responses see e.g. Heritage 2011). In example 2, for instance, the recipients have no first-hand experience of the event Pirjo is talking about. Anu, too, with her turn ja raahata jostai ('and to drag from somewhere') displays a negative attitude towards an event that she has no first-hand experience of. By using an infinitival construction, she can deal with focal elements of Pirjo's story and yet at the same time present her own assessment in a de-particularized manner, without attempting to enter directly into Pirjo's experience. In this way, she presents a critical assessment of a type of a process that she finds ridiculous, rather than something that she has directly experienced (cf. ibid.; Goodwin and Goodwin 1987: 27, 1992: 165, 182; Sorjonen 2001: 164; Heritage 2011) (Visapää forthc.).

Visapää (2008) thus suggests that the use of infinitive constructions is motivated by the ongoing action - they get used in contexts in which there is a need for displaying affect and/or empathy in such a way that the process is described only minimally with respect to the participants, time and modality. The morphosyntax of infinitives serves the kind of action carried out (e.g. affective evaluation), because it takes part in construing the speech situation. In order to fully describe the intricate ways in which this happens we need to understand the ways in which infinitives conceptualize the evaluated processes as well as the ways in which they construe the ongoing speech situation. For such a description, we need an approach that provides us with a solid framework for the description of semantic phenomena.

\subsection{Summary}

In this section, we have discussed Finnish demonstratives and A-infinitives in order to show how they provide speakers with means for accomplishing social actions. In the next section, we will use the cognitive grammar framework to give an account of the conventionalized semantic organizations associated with theses forms based on the analyses presented in section 2. Using demonstratives and infinitives as our examples, we will discuss two issues that concern the merging of cognitive grammar and conver- 
sation analysis: The schematic organizations of interaction that belong to grammatical meaning, and the dynamicity of the speech situation that is provided for by grammar. In addition, we will discuss a seeming contradiction between conversation analysis and cognitive grammar, namely the question of speaker centricity vs. joint construal of the speech situation.

\section{Merging Cognitive Grammar with Conversation Analysis}

One of the central claims of CG is that grammar is symbolic in nature: Linguistic constructions are inseparable form-meaning pairs, and the grammar of a language is seen to consist of the conventional form-meaning pairs available to a language user (Langacker 1987, 1991, 1999, 2008). These units include all elements that are routinely available to language users: They range from morphemes and lexemes to lexically specified idioms as well as more abstract schematic patterns, conventionalized patterns for constructing sentences, for example. All such units are said to be endowed with meaning, invoking and relying on conceptualization patterns shared by a language community. ${ }^{8}$ By choosing a certain type of lexical or grammatical construction, the speaker imposes a particular construal on its conceptual content. Linguistic meaning is thus understood as residing in conceptualization, which "consists of both conceptual content and a particular way of construing that content. The term construal refers to our ability to conceive and portray the same situation in alternate ways.” (Langacker 2008: 43.) A conception and portrayal of a situation can never be wholly neutral, as the speaker and hearer must always construe it in some specific fashion, out of the innumerable alternatives that are in principle available. (Langacker 1999: 26.)

The speakers need not of course make conscious choices between conceptualization patterns every time they are engaged in linguistic activities: The patterns are associated with linguistic structure, and the conventional units of language provide us with the means through which we typically conceptualize our experiences. Whether being aware of it or not, by choosing certain types of linguistic structures over another, we choose with them conceptualization patterns, conventionalized dimensions of meaning that are used for different purposes and actualized in various ways, always depending on their contexts of use.

As Langacker (2008: 43) points out, conceptualization is "dynamic, interactive, imagistic (as opposed to propositional), and imaginative". It is dynamic in the sense that language always unfolds through time: The interactants do not process hierarchically complex, ready-made packages of meaning, but are engaged in temporally evolving interactional situations, in which each expression updates the conception already established as the basis for discourse, thus providing the substrate for the next (Langacker 2014). The idea of dynamic conceptualization holds for both sentence-level and larger sequential phenomena: In the midst of temporally evolving interaction, we can rely on

\footnotetext{
${ }^{8}$ Whereas conventionality implies a socially shared understanding of a norm to a certain extent, form-meaning pairs are not fixed entities, shared and understood similarly by all language users. To talk about conventional meanings is, in other words, not saying that meanings do not emerge situationally. In the hands of its varied users, grammar is a constantly evolving phenomenon, up for reorganization and variation. Speakers do need a certain degree of conventionality, however, to be able to do things together; the conventional resources speakers bring to the situation might not be entirely shared, but they must be shared enough.
} 
meanings that are conventional to a certain degree, but the way in which these meanings are actualized and actually deployed in a specific interactional setting is context-specific and can only be accessed as a temporally evolving phenomenon.

Conceptualization subsumes novel as well as established conceptions; sensory, motor and emotive as well as intellectual experiences; apprehension of the physical, linguistic, social, and cultural context; and conceptions that develop and unfold through processing time (Langacker 2008: 30). Although conceptualization covers broadly defined any aspect of mental experience, cognitive grammar focuses on conceptualization that is adapted and employed for linguistic purposes (Langacker 2014).

Alongside conceptualization, an important term in CG is that of conceptualizer. The concept is used in various ways within the tradition, but Langacker centrally uses it to refer to the perspective inherently built into any utterance: The vantage point of the construal pattern selected (Langacker 2008: 445-453). The conceptualizer is the subject of conception (see e.g. Langacker 2008: 260), and it can be marked implicitly or explicitly. The speakers can mark themselves as conceptualizers (I told him that) or give the objective status of the conceptualizer to another person or several people (e.g. Bill thought that Mary thought that he wanted to invite John). The conceptualizer is also always present more implicitly (e.g. Vanessa was sitting across the table, There were children in the yard); in CG's term, this is referred to as a subjective construal of the conceptualizer, and in the sense of every construction bringing with them a certain construal of events, every grammatical construction opens up a place for such an implicitly construed conceptualizer. In addition to the various levels of conceptualizer positions that grammar offers us, the participants of the speech situation are always primary conceptualizers, as they do the conceptualizing in practice while producing and interpreting talk (see Langacker 1999: 26; Visapää 2008: 83).

In the following subsections, we will show how the various dimensions of conceptualizations can be useful in the analysis of grammatical phenomena in interactional data.

\subsection{Meaning associated with grammar includes knowledge about the schematic or- ganization of the speech situation}

Our first claim, which requires concepts from both CA and CG, is that meaning associated with grammar includes knowledge about the schematic organization of the speech situation.

Cognitive grammar has shown great interest in examining the ways in which lexical and grammatical constructions are organized and how these organizations reflect the ways in which we conceptualize human experience, based on our embodied involvement in the world. However, when cognitive linguists have explored the ways in which meanings are associated with grammar, semantic phenomena have almost invariably been analyzed within single, constructed sentences or in the context of monologic written data; the analyses typically revolve around clause-level semantic phenomena. What we would like to suggest is that semantics, as dealt with in CG, could be broadened easily. We find the description of linguistic units as inseparable form-meaning pairings useful, as it allows us to describe the conventional aspects of semanticogrammatical phenomena, but it should be improved by including the realm of interaction. In addition to conceptualization patterns associated with referential meaning, the 
cognitive repository of grammar needs to include knowledge about conventionalized organizations of interaction.

This elaboration is in agreement with Langacker's theory, as he says that the ultimate platform for interpreting all linguistic utterances is their usage context, and linguistic constructions therefore always carry information about the speech situation (e.g. Langacker 1999: 219, 2008: 220). As we know from the study of naturally occurring interaction, interaction is systematically orderly, and grammar is used to serve interaction in systematic ways. It is therefore only reasonable to assume that grammar - which emerges from interactional situations - conveys knowledge about such organizations and that this knowledge ought to be included in the description of the semantics associated with grammar. To illustrate this, we will revisit the case of free-standing infinitives, as discussed in section 2. We pointed out that the morphosyntax of infinitives serves the kind of action carried out (e.g. affective evaluation) and that in order to understand how this happens, we need to get hold of the ways in which they construe the speech situation.

As mentioned in 2.2, the starting point of Visapää's analysis is that the Ainfinitives construe their semantic content in a different way than finite clauses do. By semantic content we do not refer to all the lexical meaning activated but quite simply to the process and the participants referred to or activated by the verb functioning as the construction's base. In Finnish, a finite clause grounds, in one way or another, the process and its participants with respect to the interlocutors, time and modality, as the finite verb is marked for the categories of person, time and mood. Independently used Ainfinitives, on the other hand, lack such marking. They thus conceptualize the process differently, only profiling the process and leaving its relationship to person, time and mood unmarked. In this way, constructions built around an infinitive provide the interactants with a way to talk about processes without conceptualizing them with respect to interlocutors, time and modality. It is precisely this that makes them useful in sequences involving affect display, as the morphosyntactic unmarkedness brings with it a symmetrical organization of the speech situation, e.g., of the ground.

With the concept of grounding, Langacker (1987, 1990, 1991b: 53, 1999: 219220) refers to the grammaticized means with which speakers organize the relationship of linguistic elements and the speech situation, with respect to all the knowledge they have about the ongoing situation. When infinitives are used as complements of finite clauses, they are grounded by the finite verb of the matrix clause. As independent constructions, though, they remain grammatically ungrounded: They do not conceptualize the relationship of the utterance and the ground as part of their semantics. In such cases, "the ground is neither mentioned nor invoked in any capacity other than its universal role as the viewing platform" (see Langacker 1999: 219).

As the speech situation is the ultimate conceptualization platform of all linguistic expression, grounding makes no fundamental distinction between what are traditionally referred to as indexical or deictic elements of language and other linguistic units. Units that do not include any grammaticized elements of the relationship of the utterance and speech situation, e.g. infinitives, might thus be grammatically ungrounded, but they are, however, always grounded by language use. Even utterances that do not include elements referring to the speech situation in an explicit way can only be interpreted in its framework. They are, in other words, indexical - like all language use is. (See also Heritage 1996: 151-160.) 
What makes constructions such as infinitives interesting is that while they are interpreted with respect to the ongoing action, they do not include any fixed organization of the ground, and we propose that this projects an organization of the speech situation as such. As infinitives, for instance, do not position any kinds of asymmetries between the interactants with respect to participant roles, time or modality, they impose - or invite - a symmetrical organization of the ground. Consequently, they posit no distinctions with respect to the dimensions of involvement, epistemicity or knowledge: Anyone who can recognize the type of process being talked about can identify with it, and the infinitive can be used to comment on others' experiences without directly entering them. By virtue of not being specified with respect to participants, time and modality, ungrounded constructions thus offer a place for a "shared" perspective and can thereby display and invite shared understandings of the situations evaluated.

Finnish A-infinitives being only one example, we nevertheless suggest that grammar carries with it schematic organizations of the speech situation and provides us with means for constructing the very situation itself. The ground can be explicitly construed or certain aspects of it can be left unspecified, which in itself can be seen as a certain type of construal. Constructions such as free-standing A-infinitives are not explicitly marked for participants, time and modality, but despite this - or very much because of it - they take the speech situation in their focus, suggesting a shared understanding of the here-and-now of the situation.

\subsection{Interlocutors conceptualize both the world and the speech situation}

Our second claim is that interlocutors conceptualize not only the world but also the speech situation. As stated above, the starting point for cognitive grammar is the statement that grammar is meaningful. We will propose that there are grammatical means for construing the speaker ${ }^{9}$ as the primary conceptualizer or for implying that the participants of a conversation have an equal status as conceptualizers.

Grounding elements, i.e. the elements that specify the relation of the profiled entity to the ground, are used for conceptualizing some facets of the ground. In more mainstream linguistic terminology, grounding elements are thus the indexical elements of language, e.g. articles, pronouns, demonstratives and particles. In conversation analysis, the speech situation is understood as profoundly dynamic and co-constructed, and interactional studies on indexicals suggest that the meanings of the indexical elements of language serve the purpose of organizing and creating the speech situation in interaction (Hanks 1990, 2005; Laury 1997; Sorjonen 2001; Etelämäki 2009). Merging the cognitive and interactional views on indexicals, we suggest that the grounding elements of language are used for construing the ground dynamically in interaction: In every speech situation they construe the ground on the basis of the conventional organizations that they convey.

In section 2.1 we proposed that Finnish demonstratives are used for positioning the participants and the referent in relation to each other, and for creating different kinds attentional foci and access to the referent. We will now explicate this by using the notion of conceptualizer and the idea of a dynamic construal of the speech event: We propose that the Finnish demonstratives are used for expressing who is the primary concep-

${ }^{9}$ By speaker we refer roughly to the same thing as Goffman (1981) does with the notion of $a u$ thor, i.e. to the one who is responsible for the selection of the words and sentiments to be expressed. 
tualizer of the referent. Furthermore, we will use the image schematic notion of path for explicating the idea of "under observation" or "known enough for the purposes at hand”.

In cognitive grammar, demonstratives are claimed to profile the grounded entity, which is a thing, and not the grounding relationship (Langacker 2008: 122, 282). This means that the immediate scope (IS) of their predication is the entity that is being profiled, i.e. the referent. ${ }^{10}$ However, since they necessarily evoke some aspect of the ground, the ground belongs to the maximal scope (MS) of their predication. The scope of predication means the maximal conception that the demonstratives evoke. (Langacker 2002.) This kind of thinking can be combined with the dynamic understanding of referential indexicals (Silverstein 1976; Hanks 1991, 2005): They are used not only to point at a referent according to its apriori existing relation to the ground, but to point at a referent and simultaneously to create and organize the ground. In addition, in cognitive grammar demonstratives are claimed to be used for establishing coordinated mental reference between the speaker and the hearers and to express that the referent belongs to either a proximal or distal region with respect to the speaker. The distance need not be spatial, but can also be e.g. temporal or attitudinal (Langacker 2008: 281-284).

We support the idea that demonstratives profile a thing and that the ground (or some facet of the ground) belongs to their maximal scope of predication; however, as shown in section 2.1, our findings from conversational data do not support the spatial view nor the view that speaker and hearer can be strictly separated. Instead, we propose that Finnish demonstratives organize the ground with respect to who is the primary conceptualizer, and whether they create a path from the conceptualizer to the referent or not. We thus use the basic understanding of the semantics of demonstratives as presented in cognitive grammar, but our description differs from the description given in cognitive grammar.

In extract 1 (see section 2.1) Taru uses the demonstrative tämä when she initiates the troubles telling, and presents the problem with her hand. Later on she uses the demonstrative tämä (not shown in the extract) when she describes the pain in her hand. She thus uses the demonstrative tämä for conceptualizing the referent as such that only she has direct access to at the moment when the utterance is produced; furthermore, she uses the pronoun tämä when implementing an action such as a troubles-announcement, in which paying attention to and observing the referent is relevant. Based on this, we suggest that the Finnish demonstrative tämä expresses that at the moment when the utterance is produced, the recipient has access to the referent only via the conceptualization that is given in the utterance with the demonstrative tämä. In the default case then, the primary conceptualizer is the speaker (in the case of direct reported speech the conceptualizer would be the speaker of the original speech event). In figure 1 below, this is illustrated by excluding the recipient $(\mathrm{R})$ from the conceptualizer $(\mathrm{C})$. We describe the access from the conceptiualizer to the referent as a path (cognitive or sensory), which is illustrated by an arrow from the conceptualizer (C) to the referent (OR). ${ }^{11}$

\footnotetext{
${ }^{10}$ With the term referent we refer to dynamic mental representations: The images that the participants have of the referents are dynamic and change as the conversation proceeds. (See e.g. Lambrecht 1994: 37-38; Cornish 1999: 25-47.)

${ }^{11}$ The figures are not meant to be direct and comprehensive accounts of the conceptual structure conveyed by Finnish demonstratives. They illustrate certain facets of their meaning that we find prominent. Furthermore, the figures are heuristic in nature: They force the analyst to an explicitness that "facil-
} 
Figure 1: The demonstrative tämä

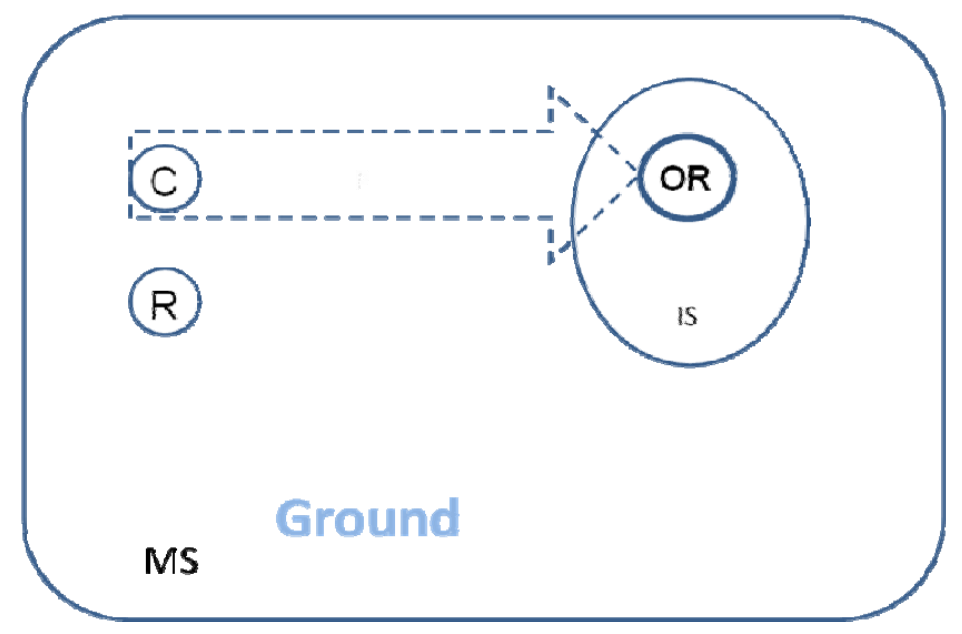

Like the Finnish demonstrative tämä, the demonstrative tuo also opens up a path from the conceptualizer to the referent (figure 2). Unlike the demonstrative tämä, it does not exclude the recipient from the place of the conceptualizer: It offers a shared access to the referent. In extract 1 it is used when the participants are working up the problem together (lines 11, 13 and 37). Observing the referent is relevant when doing diagnosis of the rash in the hand, and shared access is relevant when co-diagnosing the hand: Without access to the referent Kati could not take part in diagnosing it. Particularly line 37 is noteworthy: It comes after the closing up of the troubles-telling sequence has been initiated (l. 19-28), and re-opens the working up the problem phase again. So the demonstrative is clearly not used to match external conditions, but to dynamically create and index the activities.

Figure 2: The demonstrative tuo

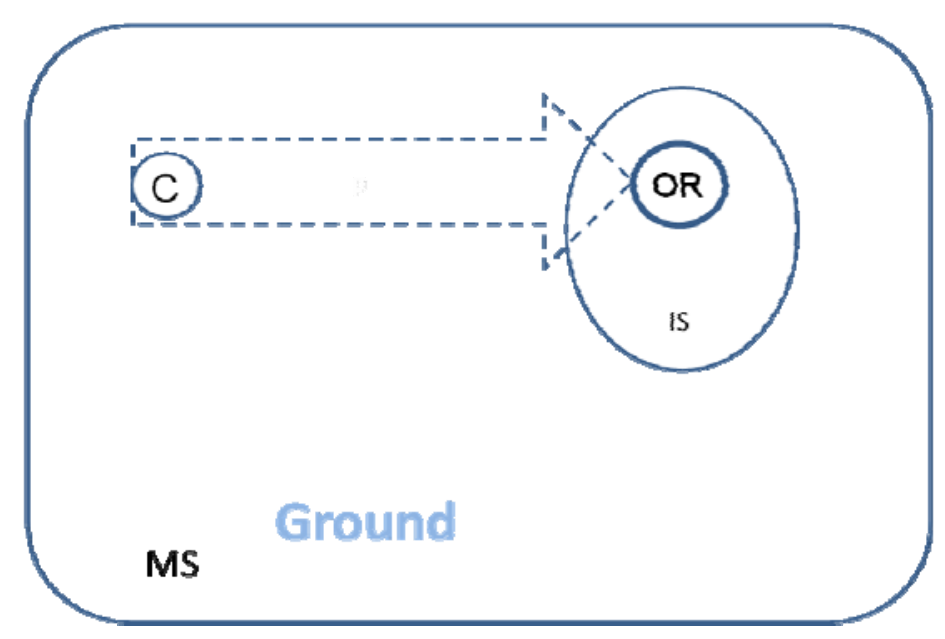

itates discovery”. We are not claiming that they are precise images of the conceptual structure of the demonstratives. Their purpose is to illustrate our current understanding of the demonstratives, and to serve as basis for further analyses. (See Langacker 2008: 9-12.) 
The demonstrative se differs from the demonstratives tämä and tuo in that it merely refers: It doesn't point at or direct attentional focus to the referent. In other words, it lacks demonstrative force. In our understanding, it does not evoke a path from the conceptualizer to the referent. Instead, it merely marks that there is a referent and this referent is known enough for the purposes at hand (figure 3 ). In the extract, the pronoun se is used in lines 6-7 and 20-26. Lines 6-7 are a response to a troubles announcement: This is a display of empathy. The pronoun se marks the referent as known enough for the purposes at hand: It is known enough for affiliating with the emotional stance at the moment. Lines 20-26 then are leading towards closing the troubles telling sequence: The problem at hand has been dealt with, and the referent is no more under observation. In addition to implying that the referent is known enough, the demonstrative se implies a shared ground with respect to the referent: This means that the speaker and the recipient(s) have an equal status as conceptualizers of the referent.

Figure 3: The demonstrative se

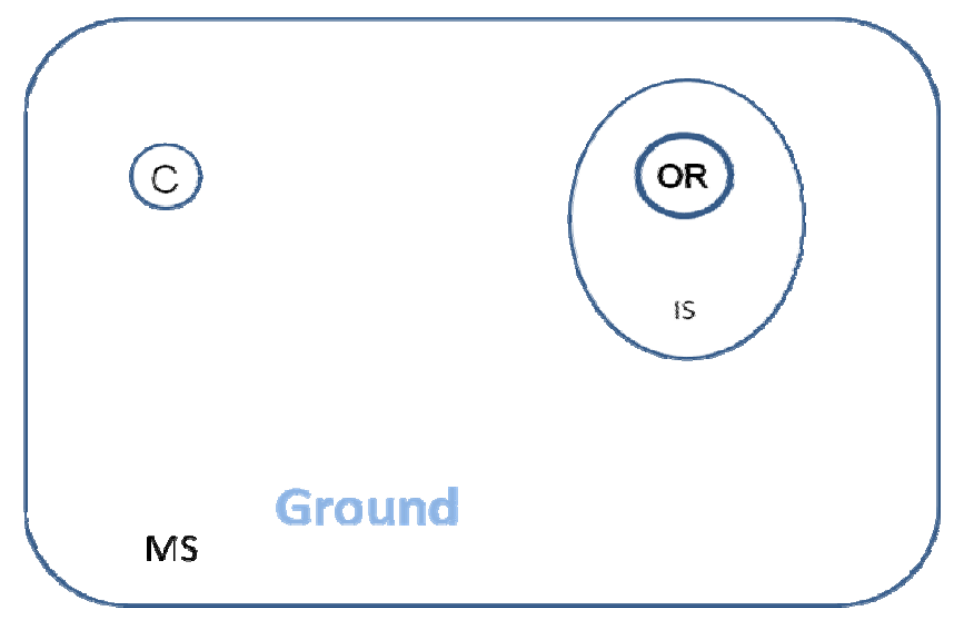

The demonstratives tuo and se are alike with respect to how they construe the conceptualizer. Since the sharedness of the ground is merely implied - not marked - we would like to suggest that an asymmetric situation is the default situation (see also Etelämäki 2006, 2009; Visapää 2008): In a default situation the participants of a conversation act jointly in a shared world. When asymmetries occur, language comes into play - or rather when language comes into play, asymmetries come into being.

In sections 3.1 and 3.2 we have proposed that there are schematic organizations of the speech situation that are conventionalized in grammatical meanings, and that grammar is used for construing the speech situation. In section 3.3 we will discuss how these organizations are a resource for the participants of an interaction to construe the speech situation jointly.

\subsection{Conceptualizations provided by grammar make dynamic joint construction pos- sible}

Langacker stresses, especially in his recent works, that conceptualization is inherently dynamic and temporally processed. We can make meaningful choices by choosing a 
certain grammatical pattern and by modifying and altering it in the course of interaction (see e.g. 2001, 2014). With demonstratives and infinitives, we hope to have shown that grammar contributes to construing actions in interaction: Conceptualizations of the speech event are part of grammatical meaning. In this section, we will discuss the seeming speaker centricity of cognitive grammar (see Laury 2002; Etelämäki et al. 2009), and propose that the grammatical means for conceptualizing the speech situation make a dynamic co-construction of the speech situation possible.

In conversation analysis, the view is that talk-in-interaction is co-constructed in various ways: Meanings as well as the course of the conversation are constantly negotiated. A central point is that conversation is thoroughly interactional. Every turn is interpreted as displaying an understanding of its prior turn (unless "some special techniques are used to locate some other talk to which it is directed”, Sacks, Schegloff \& Jefferson 1974). These displays are an important resource for the participants of a conversation as well as for an analyst, because every "second" turn provides the speaker of the "first" turn an opportunity to see if what s/he intended was indeed understood, and if it was accepted or not. These displays provide a basis for the repair mechanism, and the repair mechanism provides an opportunity to catch and deal with possible troubles in the ongoing interaction. If no repair is initiated, the progress of the conversation is understood to be achieved in mutual understanding and agreement. (See e.g. Schegloff \& Sacks 1973; Sack, Schegloff \& Jefferson 10974; Schegloff 1992.) This way the interpretations of every "first" turn that are displayed in every "second" turn, and the acceptances (either explicit, or implicit in that they are acceptances on the basis that there is no repair or repair initiation) of the interpretations in every "third" turn form a system for coproducing situated meanings. Situated meanings arise only between the participants, they are momentary and profoundly context-bound. They do not correspond to any individual's intentions or interpretations: Neither the participants nor an analyst can have direct access to other people's minds, they only have access to what is happening in the conversation.

On the surface, this seems to contradict the view that is presented in cognitive grammar. Langacker (2008: 27) states clearly that "meanings are to be found in the minds of the speakers who produce and understand the expressions". However, in our understanding this seeming contradiction between conversation analysis and cognitive grammar is a matter of focus rather than a genuine inconsistency between the two approaches (see also Langacker 2008: 28). Whereas conversation analysis focuses on what happens between the participants of an interaction, cognitive grammar focuses on one set of conventionalized and shared tools that is used for interaction, namely the conceptualizations provided by grammar:

”The present model identifies this 'internal' grammar as its object of description, conceiving it dynamically, as a constantly evolving set of cognitive routines that are shaped, maintained, and modified by language use. A speaker's 'knowledge' of his language is therefore procedural rather than declarative, and the grammar of a language is equated with certain linguistic abilities (mental, perceptual, and physical), which do not necessarily constitute an autonomous or well-delimited psychological entity. More specifically, the grammar of a language is defined as those aspects of cognitive organization in which resides a speaker's grasp of established linguistic convention. It can be characterized as a structured inventory of conventional linguistic units.” (Langacker 1987: 57.) 
Even though Langacker uses the term speaker, it is not used to refer to a solitary individual. It is used as a general term to refer to anybody who knows the language and is capable of being either an actual speaker or a recipient in an actual speech situation (1987: 57, footnote). In cognitive grammar, grammar is hence viewed as a repository of socially shared conventions, including conventional ways of managing interaction (see also Langacker 2001: 145-147). We understand these socially shared conventions to reside - at least partly - in the (socially shaped) minds of individual speakers. We therefore propose that in principle, cognitive grammar is not in contradiction with the view that talk-in-interaction is a dynamic interactional product, nor with the view that there are situated meanings that arise in interaction and are not necessarily in any one mind, but instead are shared between the participants. Its focus is on the ways of conceptualization that are conventionalized in grammatical structures. It can hardly be denied that a certain amount of conventionalization is needed in order for co-construction: In order for participants to negotiate meanings they need to have something to begin with.

What has been largely lacking from Langacker's cognitive grammar is the use of naturally occurring data instead of introspection, which has led to inaccuracies in the description of grammatical means for construing the speech situation and accomplishing social actions. ${ }^{12}$ However, there is a growing body of research within the cognitive grammar framework that is based on actual data (e.g. Onikki 2001; Leino 2003; Jaakola 2004; Visapää 2008; see also e.g. Gries \& Stefanowitsch 2006; Glynn \& Fischer 2010). These studies have mostly used written data. We wish to expand the scope of cognitive grammar to include interaction. In our view, the best way to approach ways of managing interaction that are conventionalized in grammar is to look for recurrent patterns of interaction in the data, and to base the analysis on the interpretations by the participants. In sections 3.1 and 3.2 we have shown some possible ways of construing the speech situation by grammatical means, and suggested that infinitives and demonstratives convey concetualizations of the speech situation.

When focusing on conceptualization we are interested in the ways in which linguistic structures ranging from single morphemes to larger constructions ${ }^{13}$ are used for dynamically conceptualizing the situation itself. Although much still needs to be done in this line of research, we assume, at least for the moment, that they are used for conceptualizing the relations of the participants to each other and to what is being said and done with turns-at-talk (e.g. pronouns, particles, affective stance markers), in other words, the ground at a given moment. Also, linguistic structures are used to regulate the relations of actions to other actions in sequences of actions (e.g. connectives, particles). Studying these would further the understanding of the linguistic means in and through which interaction evolves in time and gets its shape. The benefits of giving a cognitive interpretation to these uses of grammar would be to discover schematic organizations conveyed by grammar that are used in human interaction.

12 To be fair, it needs to be noted that the lack of data is a shortage recognized by Langacker himself (2001: 143-144): "I will not be presenting any actual discourse data or any detailed analysis. My concern is rather to articulate how Cognitive Grammar and discourse might be brought together, as a matter of principle.”

${ }^{13}$ In cognitive grammar, lexicon and grammar are seen as forming a continuum: Grammar consists of symbolic assemblies of varying sizes and levels of specificity, see e.g. Langacker 2008: 18-19. 


\section{Discussion}

In this article, we have proposed that cognitive grammar offers a suitable theoretical framework for interactional studies of language, and especially for the findings of conversation analysis. Using Finnish demonstratives and infinitives as examples, we have discussed how interactional functions of language can be described in the framework of cognitive grammar. We have proposed that there are schematic organizations of the ground, i.e. the speech event, that are conventionalized in grammar. In addition to conveying oganizations of the ground, we assume that there are schematic ways of relating actions to other actions in a sequence of actions, and that these are crystallized in e.g. particles. This, however, is a subject for further research.

Parts of interactional knowledge are abstracted into grammar just as anything becomes part of our grammatical knowledge, as recurrent schemas that start to function as cognitive routines. As Langacker puts is:

\footnotetext{
"Usage events are the source of all linguistic units. - In each case, units emerge via the progressive entrenchment of configurations that recur in a sufficient number of events to be established as cognitive routines. Since only recurring features are reinforced, the units that emerge are far less comprehensive and detailed than the usage events giving rise to them.” (Langacker 2008: 220.)
}

The idea of interactional schemas that are conveyed by grammar might prove useful in considering how social actions are accomplished by linguistic structures. In this article, we have stated that the way demonstratives and infinitives organize the ground is useful for the actions that the turns they occur in are accomplishing. We propose that further studies of the ways in which the ground is construed for accomplishing actions would further the understanding of actions in interaction, and also provide a basis for comparative analysis across languages and cultures. In addition, as has been shown, it is probable that there are particular linguistic formats that are used for accomplishing particular actions, i.e. there are specific formats with specific functions (see e.g. Couper-Kuhlen, this volume). However, we assume that all interaction is not based on one-to-one mapping of a linguistic format and action, but that there are more schematic meanings conveyed by e.g. indexicals that allow for flexible interpretations and accomplishment of actions in various contexts, i.e. that they are adaptable according to unique situations.

As has been pointed out by several studies, face-to-face interaction is the natural home for speech, as language evolves in social interaction both phylogenetically and ontogenetically (Schegloff 1996; Zlatev 2008; Hasson et al. 2012). Several recent studies from different fields of research also point out that humans are inherently social beings (e.g. Levinson 2006; Evans \& Levinson 2009; Noordzij at al. 2009; Hasson et al. 2012; Zlatev 2008), and that language is a product - as well as an intrinsic part - of human sociality. There may very well be similar schemas structuring actions and grammar (see also Auer 2005), and parts of the knowledge about social interaction patterns may get conventionalized in linguistic structures (see also Linell 1998, 2004, 2009).

We propose an approach to language where grammar is analyzed as the interface of the human mind and the social world. In our view, taking a cognitive step in the interactional studies of language could not only be a bridge between cognitive and interactional studies of language, but could also be informative for human sociality in general, building a bridge between different fields of research such as social neuroscience, social studies and linguistics. 


\section{Abbreviations used in glossing}

\section{Nominal markings}

ABL

ablative

ACC

accusative

ADE

adessive

ELA elative

ESS essive

GEN genitive

ILL illative

INES inessive

PL plural

PTV partitive

TRA translative

\section{Verbal markings}

$\begin{array}{ll}\text { A-INF } & \text { a-infinitive } \\ \text { MA-INF } & \text { ma-infinitive } \\ \text { 1SG } & \text { 1st person singular } \\ \text { 3SG } & \text { 3rd person singular } \\ \text { COND } & \text { conditional } \\ \text { IMP } & \text { imperative mood } \\ \text { NEG } & \text { negation } \\ \text { PST } & \text { past } \\ \text { PAS } & \text { passive } \\ \text { PAS-PC } & \text { passive present participle } \\ \text { PPC } & \text { active past participle }\end{array}$

\section{Other}

$\begin{array}{ll}\text { 1SG } & \text { 1st person singular pronoun } \\ \text { 2SG } & \text { 2nd person singular pronoun } \\ \text { ADJ } & \text { adjective } \\ \text { CLI } & \text { clitic } \\ \text { CONJ } & \text { conjunction } \\ \text { DEM } & \text { demonstrative } \\ \text { LOC } & \text { locative adverb } \\ \text { POSS } & \text { possessive suffix } \\ \text { PRT } & \text { particle } \\ \text { Q } & \text { question particle }\end{array}$

\section{Demonstratives}

$\begin{array}{ll}\text { DEM1 } & \text { tämä } \sim \text { tää } \\ \text { DEM2 } & \text { tuo } \sim \text { toi } \\ \text { DEM3 } & \text { se }\end{array}$


DEM2.PL $\quad$ nuo $\sim$ noi

DEM3.PL ne

\section{References}

Auer, Peter (2005) Projection in interaction and projection in grammar. Text 25.1: 7-36.

Barlow, Michael, and Suzanne Kemmer (eds.) (2000) Usage Based Models of Language. Stanford: CSLI.

Bybee, Joan, and Paul Hopper (eds.) (2001) Frequency and the Emergence of Linguistic Units. Amsterdam: John Benjamins Publishing Company.

Cornish, Francis (1999) Anaphora, Discourse and Understanding: Evidence from English and French. Oxford: Clarendon Press.

Couper-Kuhlen Elizabeth (this volume) What does grammar tell us about action? Pragmatics 24.3: 623647.

Croft, William (2009) Towards a social cognitive linguistics. In V. Evans, and S. Pourcel (eds.), New Directions in Cognitive Linguistics. Amsterdam: John Benjamins Publishing Company, pp. 395-420.

Diessel, Holger (2006) Demonstratives, joint attention, and the emergence of grammar. Cognitive Linguistics 17: 463-489.

Enfield, N.J. (2003) Demonstratives in space and interaction. Data from Lao speakers and implications for semantic analysis. Language 79: 82-117.

Etelämäki, Marja (2006) Toiminta ja tarkoite.Tutkimus suomen pronominista "tämä" [Activity and referent. A study on the Finnish pronoun tämä]. Helsinki: Finnish Literature Society.

Etelämäki, Marja (2009) The Finnish demonstrative pronouns in light of interaction. Journal of Pragmatics 41: 21-46.

Etelämäki, Marja, and Minna Jaakola (2009) Tota ja puhetilanteen todellisuus [The particle tota and the reality of speech situation]. Virittäjä 2: 188-212.

Etelämäki, Marja, Minna Jaakola, Ilona Herlin, and Laura Visapää (2009) Kielioppi käsitteistyksenä ja toimintana. Kognitiivista kielioppia ja keskustelunanalyysia yhdistämässä. [Grammar as conceptualization and as action. Combining Cognitive Grammar and Conversation Analysis]. Virittäjä 2: 162-187.

Evans, Nicholas, and Stephen C. Levinson (2009) The myth of language universals. Language diversity and its importance for cognitive science. Behavioral and Brain Sciences 32: 429-448.

doi: http://dx.doi.org/10.1017/S0140525X0999094X

Fillmore, Charles J. (1988) The mechanisms of "construction grammar". In Proceedings of the Annual meeting of the Berkeley Linguistic Society 14: 35-55.

Ford, Cecilia, and Barbara Fox (1996) Interactional motivations for reference formulation: He had. This guy had, a beautiful, thirty-two O:Ids. In B.A. Fox (ed.), Studies in Anaphora. Amsterdam: John Benjamins Publishing Company, pp. 145-168. 
Ford, Cecilia, Barbara Fox, and Sandra A. Thompson (2002) Constituency and turn increments. In C. Ford, B. Fox, and S. Thompson (eds.), The Language of Turns and Sequences. Oxford: Oxford University Press, pp. 14-38.

Ford, Cecilia, Barbara Fox, and Sandra A. Thompson (2003) Social interaction and grammar. In M. Tomasello (ed.), The New Psychology of Language: Cognitive and Functional Approaches to Language Structure, Vol. 2. London: Erlbaum, pp. 119-144.

Glynn, Dylan, and Kerstin Fischer (eds.) (2010) Quantitative Methods in Cognitive Semantics: Corpusdriven Approaches. Berlin/New York: Mouton de Gruyter.

Goffman, Erwing (1981) Forms of Talk. Philadelphia: University of Pennsylvania Press.

Goodwin, Charles (1979) The interactive construction of a sentence in natural conversation. In G. Psathas (ed.), Everyday Language: Studies in Ethnomethodology. New York: Irvington Publishers, pp. 97-121.

Goodwin, Charles (2003) Pointing as Situated Practice. In S. Kita (ed.), Pointing: Where Language, Culture and Cognition Meet. Mahwah, NJ: Lawrence Erlbaum, pp. 217-241.

Goodwin, Charles, and Marjorie Harness Goodwin (1987) Concurrent operations on talk: Notes on the interactive organization of assessments. Pragmatics 1.1: 1-55.

Gries, Stefan Th., and Anatol Stefanowitsch (eds.) (2006) Corpora in Cognitive Linguistics: Corpusbased Approaches to Syntax And Lexis. Berlin: Mouton de Gruyter.

Günthner, Suzanne (2000) Vorwurfsaktivitäten in der Alltagsinteraktion. Tübingen: Niemeyer.

Hakulinen, Auli (ed.) (1989) Suomalaisen keskustelun keinoja I . [Characteristics of Finnish Conversation I]. Kieli 4. Department of Finnish, University of Helsinki.

Hakulinen, Auli (2001) On some uses of the discourse particle kyllä in Finnish conversations. In E. Couper-Kuhlen, and M. Selting (eds.), Studies in Interactional Linguistics. Amsterdam: John Benjamins Publishing Company, pp. 171-198.

Hakulinen, Auli, and Eeva-Leena Seppänen (1992) Finnish kato: from verb to particle. Journal of Pragmatics 18: 527-549.

Hanks, William F. (1990) Referential Practice. Language and Lived Space among the Maya. Chicago: The University of Chicago Press.

Hanks, William F. (1992) The indexical ground of deictic reference. In A. Duranti, and C. Goodwin (eds.), Rethinking context. Language as an interactive phenomenon. Cambridge: Cambridge University Press, pp. 43-76.

Hanks, William F. (2005) Explorations in the deictic field. Current Anthropology 46.2: 191-220.

Heritage, John (1996 [1984]) Harold Garfinkel ja etnometodologia. [Garfinkel and Ethnomethodology]. Transl. I. Arminen, O. Paloposki, A. Peräkylä, S. Vehviläinen, and S. Veijola. Helsinki: Gaudeamus.

Heritage, John (2011) Territories of knowledge, territories of experience: Empathic moments in interaction. T. Stivers, L. Mondada, and J. Steensig (eds.), The Morality of Knowledge in Conversation. Cambridge: Cambridge University Press, pp. 159-183.

Hasson, Uri, Asif A. Ghanzafar, Bruno Galantucci, Simon Garrod, and Christian Keysers (2012) Brainto-brain coupling: A mechanism for creating and sharing a social world. Trends in Cognitive Science 16: $114-121$. 
doi:10.1016/j.tics.2011.12.007

Itkonen, Terho (1966) Tutkimus suomen asyndetonista. [A study on Finnish asyndeton]. Virittäjä 70: 402-423.

Itkonen, Terho (1979) Zur Sematik und Pragmatik der Finnischen Demonstrativa. In C. Gläser, and J. Pustzay (eds.), Festschrift für Wolfgang Schalchter zum 70. Geburtstag. Veröf fentlichungen der Societas Uralo-Altaica 12. Wiesbaden: Harrassowitz, pp. 113-127.

Jaakola, Minna (2004) Suomen genetiivi [Finnish genitive]. Helsinki: Finnish Literature Society.

Jefferson, Gail (1988) On the sequential organization of troubles talk in ordinary conversation. Social Problems 35.4: 418-442.

Keevallik, Leelo (2003) From Interaction to Grammar. Estonian Finite Verb Forms in Conversation. Uppsala, Sweden: Studia Uralica Upsaliensia 34.

Kemmer, Suzanne (2011) Functions in the individual and in the community. Paper presented at the Symposium on Functions, Functionalism and Linguistics. LSA Winter Meeting, Pittsburgh, January 2011.

Koivisto, Aino (2012) Discouse patterns for turn-final conjunctions. Journal of Pragmatics 44: 12541272.

Laitinen, Lea (1995) Nollapersoona. [Zero person]. Virittäjä 99: 337-358.

Laitinen, Lea (2006) Zero person in Finnish. A grammatical resource for construing human evidence. In M-L. Helasvuo, and L. Campbell (eds.), Grammar from the Human Perspective. Case, space and person in Finnish. Amsterdam: John Benjamins Publishing Company, pp. 209-232.

Lambrecht, Kund (1994) Information Structure and Sentence Form. Topic, Focus and the Mental Representatins of Discourse Referents. Cambridge: Cambridge University Press.

Langacker, Ronald W. (1987) Foundations of cognitive grammar. Volume 1: Theoretical prerequisites. Stanford: Stanford University press.

Langacker, Ronald W. (1990) Subjectification. Cognitive Linguistics 1: 5-38.

Langacker, Ronald W. (1991) Foundations of Cognitive Grammar. Volume II: Descriptive Application. Stanford, California: Stanford University Press.

Langacker, Ronald W. (1999) Grammar and Conceptualization. Berlin: Mouton de Gruyter.

Langacker, Ronald W. (2001) Discourse in Cognitive Grammar. Cognitive Linguistics 12: 143-188.

Langacker, Ronald W. (2002) Deixis and subjectivity. In F. Brisard (ed.), Grounding. The Epistemic Footing of Deixis and Reference. Berlin: Mouton de Gruyter, pp. 1-28.

Langacker, Ronald W. (2008) Cognitive grammar. A basic introduction. Oxford: Oxford University Press.

Langacker, Ronald W. (2014) Subordination in a dynamic account of grammar. In J. Kalliokoski, H. Sorva, and L. Visapää (eds.), Contexts of Subordination. Cognitive, typological and discourse perspectives. Amsterdam: John Benjamins Publishing Company, pp. 17-72.

Larjavaara, Matti (2007) Pragmasemantiikka [Pragma-semantics]. Helsinki: Finnish Literature Society.

Laury, Ritva (1997) Demonstratives in Interaction. The emergence of a definite article in Finnish. Amsterdam: John Benjamins Publishing Company. 
Laury, Ritva (2002) Interaction, grounding and third-person reference forms. In F. Brisard (ed.), Grounding. The Epistemic Footing of Deixis and Reference. Berlin: Mouton de Gruyter, pp. 83-111.

Leino, Jaakko (2003) Antaa se muuttua. Suomen kielen permissiivirakenne ja sen kehitys. [Let it change. The Finnish permissive construction and its history]. Helsinki: Finnish Literature Society.

Levinson, Stephen C. (2006) On the human “interaction engine”. In S.C. Levinson, and N.J. Enfield (eds.), Roots of human sociality. Oxford: Berg, pp. 39-69.

Linell, Per (1998) Approaching dialogue: Talk, interaction and contexts in dialogical perspectives. Amsterdam: John Benjamins Publishing Company.

Linell, Per (2004) On some principles of a dialogical grammar. In K. Aijmer (ed.), Dialogue Analysis VIII: Understanding and misunderstanding in dialogue. Tübingen: Niemeyer, pp. 7-23.

Linell, Per (2009) Rethinking language, mind, and world dialogically. Charlotte, NC: Information Age Publishing.

Mazeland, Harrie, and Mike Huiskes (2001) Dutch but as a sequential conjuction. In M. Selting, and E. Couper-Kuhlen (eds.), Studies in Interactional Linguistics. Amsterdam: John Benjamins Publishing Company, pp. 141-169.

Mielikäinen, Aila (1991) Murteiden murros: Levikkikarttoja nykypuhekielen piirteistä. [Circulation maps of features of present-day spoken language]. Jyväskylän yliopiston suomen kielen laitoksen julkaisuja 36. Jyväskylä: University of Jyväskylä.

Noordzij, Matthijas, Sarah E. Newman-Norlund, Jan Peter de Ruiter, Peter Hagoort, Stephen C. Levinson, and Ivan Toni (2009) Brain mechanisms underlying human communication. Frontiers in Human Neuroscience 3: 14.

doi: 10.3389/neuro.09.014.2009

Onikki-Rantajääskö, Tiina (2001) Sarjoja. Nykysuomen paikallissijaiset olotilanilmaukset kielen analogisuuden ilmentäjinä. Helsinki: Finnish Literatre Society.

Ono, Tsuyoshi, and Sandra A. Thompson (1995) What can conversation tell us about syntax? In P.W. Davis (ed.), Alternative linguistics. Descriptive and theoretical modes. Amsterdam: John Benjamins Publishing Company, pp. 213-271.

Penttilä, Aarni (1963 [1957]) Suomen kielioppi [Finnish grammar]. $2^{\text {nd }}$, revised edition. Porvoo: WSOY.

Sacks, Harvey, Emanuel A. Schegloff, and Gail Jefferson (1974) A simplest systemactics for the organization of turn-taking for conversation. Language 50: 696-735.

Schegloff, Emanuel A. (1992) Repair after next turn: The last structurally provided defense of intersubjectivity in conversatin. American Journal of Sociology 97: 1295-1345.

Schegloff, Emanuel A. (1996) Turn organization: One intersection of grammar and interaction. In E. Ochs, E.A. Schegloff, and S.A. Thompson (eds.), Interaction and grammar. Cambridge: Cambridge University Press, pp. 52-133.

Schegloff, Emanuel A. (2007) Sequence Organization in Interaction. A Primer in Conversation Analysis I. Cambridge: Cambridge University Press.

Schegloff, Emanuel A. (2010) Some other “uh(m)”s. Discourse Processes 47: 130-174.

Schegloff, Emanuel A., and Harvey Sacks (1973) Opening up closings. Semiotica VIII, 4: 289-327. 
Selting, Margret (2010) Affectivity in conversational storytelling: An analysis of displays of anger or indignation in complaint stories. Pragmatics 20: 229-277.

Setälä, Emil Nestor (1880) Suomen kielen lauseoppi. Oppikirjan koe. [Finnish syntax. A textbook]. Helsinki: K.E. Holm.

Silverstein, Michael (1976) Shifters, verbal categories, and cultural description. In K.H. Basso, and H.A. Selby (eds.), Meaning in Anthropology. Albuquerque: University of New Mexico Press, pp. 11-55.

Sorjonen, Marja-Leena (2001) Responding in Conversation. A Study of Response Particles in Finnish. Amsterdam: John Benjamins Publishing Company.

Visapää, Laura (2008) Infinitiivi ja sen infiniittisyys. Tutkimus suomen kielen itsenäisistä Ainfinitiivikonstruktioista. [Infinitive and its infinity. A study of the independent A-infinitive constructions]. Helsinki: Finnish Literature Society.

Visapää, Laura (forthcoming) Infinitives revisited: An interactional and cognitive approach. Manuscript under revision.

Zlatev, Jordan A. (2008) The co-evolution of intersubjectivity and bodily mimesis. In J. Zlatev, T. Racine, C. Sinha, and E. Itkonen (eds.), The shared mind: Perspectives on intersubjectivity. Amsterdam: John Benjamins Publishing Company, pp. 215-244

Zlatev, Jordan A. (2010) Phenomenology and cognitive linguistics. In S. Callagher (ed.), Handbook on Phenomenology and Cognitive Science. Berlin: Springer, pp. 415-446.

MARJA ETELÄMÄKI is currently Coordinator of the research project Grammar and interaction: The linking of actions in speech and writing, University of Helsinki. Previously, she worked at the University of Helsinki as a post doctoral researcher in the projects Cognitive meets interactional in linguistics: Functions and grammaticalization of Finnish referential indexicals and Contexts of subordination. Lately, her research has focused on combining the method and insights of conversation analysis with the theory of cognitive grammar. Her dissertation Toiminta ja tarkoite. Tutkimus suomen pronominista tämä [Activity and referent. A study on the Finnish pronoun tämä] was published by Finnish Literature Society, Helsinki, 2006.

Address: P.O. Box 4 (Vuorikatu 3A), 00014 University of Helsinki, Finland. E-mail: etelemaki@helsinki.fi

LAURA VISAPÄÄ is a post doc scholar funded by the Foundations Post Doc Pool (2013-2014) and currently working at the Universities of Colorado (Boulder) and the University of Helsinki (Centre of Excellence in Intersubjectivity in Interaction). Her research focuses, on the one hand, on the interactional functions of single constructions (e.g. relative clauses, infinitives, negative particles); on the other hand, her interests lie in such wider questions as studying language in relation to selfhood, identity and empathy, as well as in the intersubjectivity of cognition and grammar. Since defending her dissertation on the affective functions of infinitives in 2008, Visapää has been involved in several projects, most importantly the 
project "The contexts of subordination" (Academy of Finland 2007-2010), the research group "Social mind and language", as well as the Centre of Excellence in Intersubjectivity. Currently, she is working on a conversation analytical project that aims to contribute to our understanding of how the self and the interpretations about the self are constructed, negotiated, and sustained in ongoing talk and interaction.

Address: P.O. Box 4 (Vuorikatu 3A), 00014 University of Helsinki, Finland. E-mail: laura.visapaa@helsinki.fi 